The Geographical Journal of Nepal

Vol. 15: 23-40, 2022

DOI: https://doi.org/10.3126/gjn.v15i01.42884

Central Department of Geography,

Tribhuvan University, Kathmandu, Nepal

\title{
Changing precipitation patterns in far-western Nepal in relation to landslides in Bajhang and Bajura districts
}

\author{
Janak Lal Nayava ${ }^{1, *}$, Jagat Kumar Bhusal ${ }^{1}$, Jonathan D. Paul ${ }^{2}$, Wouter \\ Buytaert $^{3}$, Bhanu Neupane ${ }^{4}$, Januka Gyawali ${ }^{4}$, Saugat Poudyal ${ }^{1}$ \\ ${ }^{1}$ Independent Hydro-meteorological Consultant, Kathmandu, Nepal \\ ${ }^{2}$ Earth Sciences, Royal Holloway, University of London, TW20 0EX, UK \\ ${ }^{3}$ Civil and Environmental Engineering, Imperial College London, SW7 2AZ, UK \\ ${ }^{4}$ UNESCO, Kathmandu, Nepal \\ *Corresponding author: drjanaklal@gmail.com \\ Received: 01 August, 2021; Accepted: 07 October, 2021; Published: March, 2022
}

\begin{abstract}
The geologically young terrains of the Nepal's Lesser Himalaya are strongly affected by the multiple and interrelated geo-hazards of landslides, floods, and debris torrents. One of the main factors that trigger these hazards is the duration and intensity of monsoon rainfall. Here, we interrogate precipitation data for a variety of different periods, the longest of which comprises 40 years (1977-2017) of annual rainfall data, for 17 rainfall stations in far-western Nepal. The average rainfall over the past 10 years (2007-2017) was found to be declining for most stations. The summer monsoon season (i.e. June to September) accounts for 70-80\% of the total annual rainfall, and is critical for agricultural production; but the vast majority of floods and landslides also occur during this time. Changes in daily rainfall magnitude and frequency are analysed. The intensity of rainfall during monsoon time was found to increase by over $100 \%$ in the past 40 years, with this change especially pronounced in 2008. The variation of intensities of rainfall in relation to landslides at different elevations has also been explored. We found that rainfall intensity increased by 40-60\% over an increase in elevation from 1 to $2 \mathrm{~km}$ in the study area of the Bajedi landslide in far-western Nepal.
\end{abstract}

Keywords: Landslide, rainfall intensity, far-western Nepal, monsoon 


\section{Introduction}

Assessments of landslide risk require a detailed understanding of the historical and current causes that may trigger landslides. The purpose of studying rainfall is to identify whether it is the root cause that triggers landslide activity, or merely acts as an important antecedent. Nepal is the $20^{\text {th }}$ most severely affected country by multi-hazards in the world (UNDRR, 2019). Over a distance of just $200 \mathrm{~km}$, elevation changes from $70 \mathrm{~m}$ to $8848 \mathrm{~m}$. This spatial variation together with highly rugged topography and soft, friable rocks, makes the country highly vulnerable to water-induced hazards such as landslides, soil erosion, floods, and debris torrents (Dahal, 2012). There are generally two main factors that trigger landslides: one natural and the other anthropogenic. Inherent natural factors include geological formation and structure, slope, aspect, land cover and ground cover conditions. External factors include earthquakes and rainfall duration/intensity. Anthropogenic factors include human interventions like deforestation, improper land use, unplanned construction and unplanned mining etc. In Nepal, the greatest number of landslides occurs in the monsoon season (Petley et al., 2007). Recently, bulldozer action on numerous unplanned roads in the Lesser Himalaya has acted as an important new landslide trigger. When we study the rainfall and its impact on landslides, it is important first to understand prior land use changes, and whether rainfall acts as a trigger or antecedent factor such as increasing soil saturation and pore-water pressures (Upreti, 2000; 2001).

Thus, an assessment of landslide risk requires understanding the historical and current causes that may trigger landslides. The purpose of this study is to understand whether landslide activity in a specific study area is largely governed by rainfall or by other causes. At the same time, we attempt to foster local awareness of landslides, their varied causes and their impacts on livelihoods. Far-western Nepal receives $70-80 \%$ of its annual precipitation during the monsoon season between June and September (Nayava, 1974; TCE, 2002), increasing the occurrence of landslides during this period of the year (Government of Nepal, 2019; World Bank, 2020). In a global landslide dataset, Nepal contributes $10 \%$ of all rainfall-induced landslide events, and $93 \%$ of all those triggered by seasonal monsoons (Froude \& Petley, 2018). Furthermore, climate change has a direct influence on frequency and intensity changes of precipitation (Fischer \& Knutti, 2015), thereby increasing the number of potential future landslides (Trenberth, 2011). Hence, it is necessary to understand the ways in which precipitation patterns are changing with time and the nature of their direct relationship with natural hazards such as landslides. 
Landslides pose serious threats to lives and livelihoods, cause hundreds of fatalities each year (Figure 1), disrupt local agricultural productivity, damage infrastructure, and cause serious economic disruption both locally and nationally (Petley et al., 2007; Froude \& Petley, 2018). Between 1971-2013, a total of 3208 landslide events were recorded, together with 4658 deaths, 623 missing people and affecting 0.59 million others indirectly, resulting in a direct economic loss of US $\$ 10.1 \mathrm{~m}$ (Desinventar, 2020).

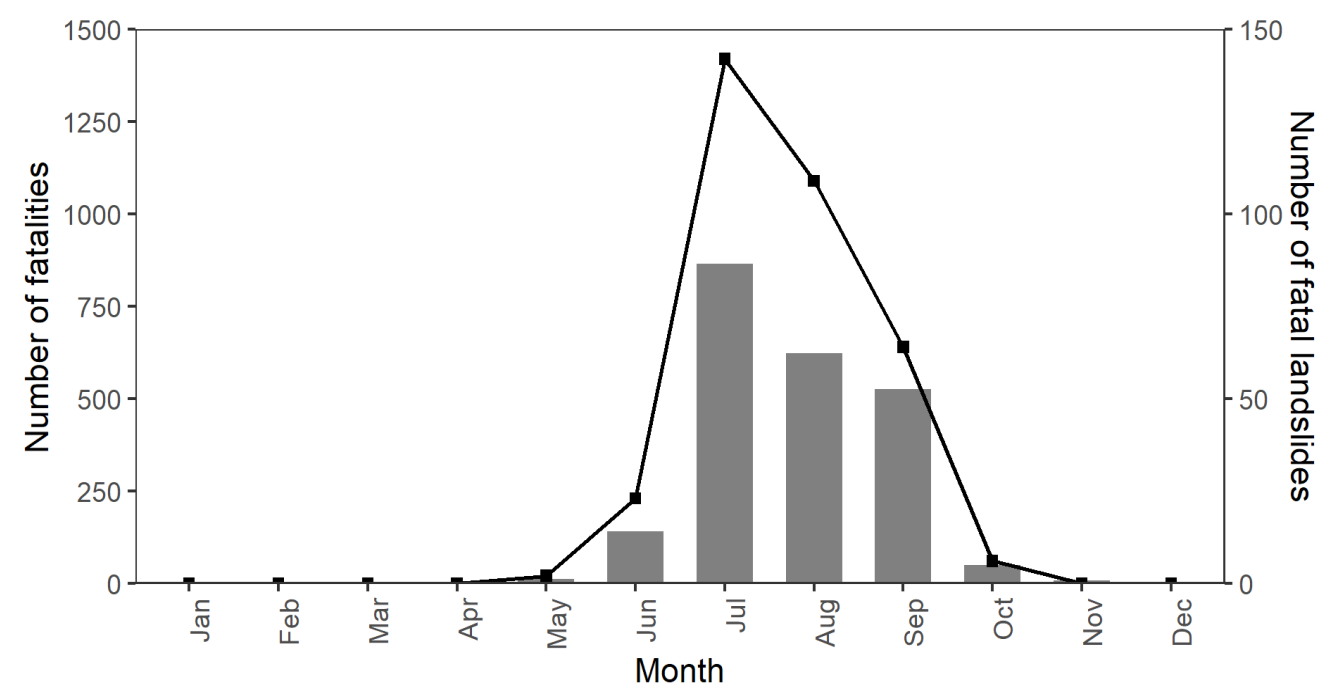

Figure 1: Comparison between the occurrence of landslide fatalities and the number of fatal landslides in Nepal for 1978-2005 (Petley et al., 2007).

There have been numerous detailed studies on the relationship between rainfall and landslides events in mountainous regions (Petley et al., 2007; Dahal, 2012; Froude \& Petley, 2018; Kirschbaum et al., 2020). In hilly regions, landslides are triggered either from prolonged rainfall of several days to weeks (Gabet et al., 2004) or from short cloudbursts (Dixit, 2003). When rainfall infiltrates hillslopes, it changes pore water pressure, reduces shear stress, and can result in slope failure (Iverson, 2000).

Landslides are very much common during the summer monsoon in Nepal: failure is generally due to cessation of rainfall as well as its high intensity. Indeed, the 2020 summer monsoon may have been one of the wettest seasons in the past 50 years in Nepal. Nayava (2017) studied monsoonal rainfall in Nepal from 1971-2015; in this context, 2020 was unique in terms of rainfall intensity and the number of landslides triggered in the Lesser Himalaya. The total loss of life and property has not yet officially been declared by the Government of Nepal $(\mathrm{GoN})$; however, the loss of property was assumed to be more than double that of 2019. Department of Hydrology and Meteorology reported 
that 2020 had the widespread wettest monsoon year. The average of daily accumulated precipitation during 2020 monsoon season indicated more than $9 \%$ than the normal accumulated precipitation in Nepal (DHM, 2021). We speculate that the very active local Monsoon season of 2020 could result from cleaner air arising from the Covid-19 pandemic (i.e. fewer flights and lower density of intensive transportation routes during national lockdown periods).

Monsoon-induced disasters such as landslides and pluvial flooding caused damage worth over US\$ 17 million on national highways so far in 2020. Indeed, during the entire monsoon season in 2019, the total figure stood at US\$ 11 million (Shrestha, 2020). Table 1 shows the impact of the most recent monsoon seasons on the human death and injury toll.

Table 1: Total fatalities, persons wounded and missing during the monsoon

\begin{tabular}{|l|r|r|r|r|r|}
\hline \multicolumn{1}{|c|}{ Year } & \multicolumn{1}{c|}{$\mathbf{2 0 1 6}$} & \multicolumn{1}{c|}{$\mathbf{2 0 1 7}$} & \multicolumn{1}{c|}{$\mathbf{2 0 1 8}$} & \multicolumn{1}{c|}{$\mathbf{2 0 1 9}$} & \multicolumn{1}{c|}{$\mathbf{2 0 2 0}$} \\
\hline Fatalities & 487 & 588 & 455 & 406 & 177 \\
\hline Wounded & 840 & 845 & 4188 & 1133 & 556 \\
\hline Missing & 49 & 65 & 10 & 40 & 19 \\
\hline
\end{tabular}

Source: Thapa, 2020

Much effort has been devoted to landslide and flooding risk reduction and resiliencebuilding programmes in Nepal (MoHA, 2009). While absolute rainfall amounts are important triggers, in July 1993, a single high-intensity cloudburst ( $70 \mathrm{~mm} / \mathrm{hour}$ ) was responsible for widespread slope failure in the Kulekhani catchments (Dixit, 2003). Meanwhile, detailed studies on the relationship between rainfall and landslides events have been conducted elsewhere in eastern Himalayas, Darjeeling, and northern India. In one such Indian study, Froehlich et al. (1990) observed rainfall exceeding $50 \mathrm{~mm}$, decreasing at a rate of $0.5 \mathrm{~mm} / \mathrm{min}$ thereafter, when slides or slumps on steep slope segments began to occur, mainly along undercut sections of roads or rivers. In this case, over 130-150 mm fell in 24 hours or $\sim 200-240 \mathrm{~mm}$ over a three-day period, leading to widespread landslide activity. This example is also applicable in the hills of Nepal. Recent studies in Sikkim province of India revealed that the threshold relationship for rainfall intensity is $1.82 \mathrm{~mm} /$ hour during the monsoon period in that region. In addition, an average precipitation of $1.05 \mathrm{~mm} /$ hour appeared to be sufficient to cause mass movement for fully-saturated soils during the monsoon (Bappaditya et al., 2019).

The purpose of this paper is to accrue a new compendium of rainfall data, and to analyse spatiotemporal changes in intensity and frequency in terms of changes 
in landslide dynamics. The remainder of the text is structured as follows. Section 2 introduces our study area in far-western Nepal, discusses rain gauge data availability and our methodology for analysing these data. Section 3 presents results of changes in precipitation; Section 4 then relates these changes to contemporaneous changes in landslide activity. Section 5 discusses these patterns in terms of regional effects of climate change; and, finally, Section 6 offers brief conclusions and a future outlook.

\section{Methodology}

\section{The study area}

This study is focused on two districts, Bajhang and Bajura, in the far-western region of Nepal (Figures 2a, 2b and 3a, 3b). Both districts are characterised by extremely rugged topography in the Lesser Himalayan Sequence (Cieslik et al., 2019), with an elevation ranging from $720-6960 \mathrm{~m}$. The specific study sites are the Bajedi and Sunkuda landslides in the Bajura and Bajhang districts, respectively. Both locations experience seasonal shallow slides ( $<1 \mathrm{~m}$ depth): rockslides in Bajedi and soil slides in Sunkuda.

The total area affected by deep-seated gravitational slope deformation (DSGSD) is about $29.8 \mathrm{~km}^{2}$ at elevations of $950-2150 \mathrm{~m}$. The bedrock is characterised by a series of overlapping quarzites and phyllites. DSGSD generates loose material and debris flow with potentially severe consequences for the communities of the lower Budhiganga river valley. Though quartzites are mechanically strong and impermeable, they are nevertheless slowly affected by rainfall penetration (Amabile et al., 2018). Moreover, the Bajura district is characterised by a relatively high density of E-W-trending thrust faults, allowing a greater degree of percolation (Parajuli et al., 2020; Paul et al., 2020).

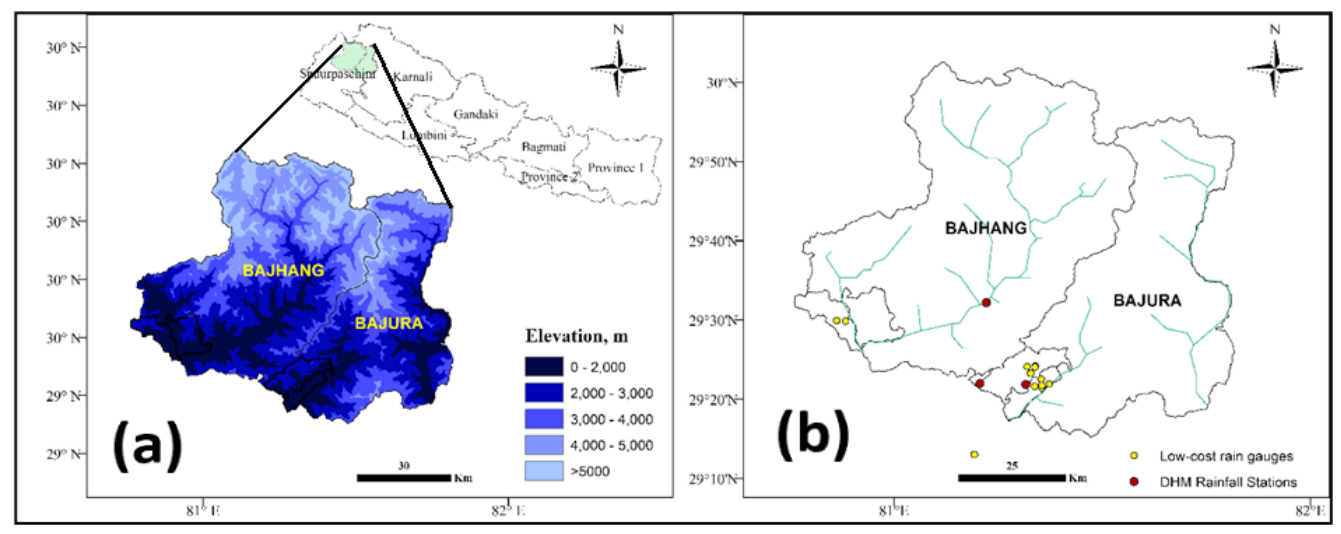

Figure 2: (a) Location map of the study area; (b) meteorological networks established by the Government of Nepal (GoN), Department of Hydrology and Meteorology (DHM); and community-owned automatic tipping-bucket rain gauges. 

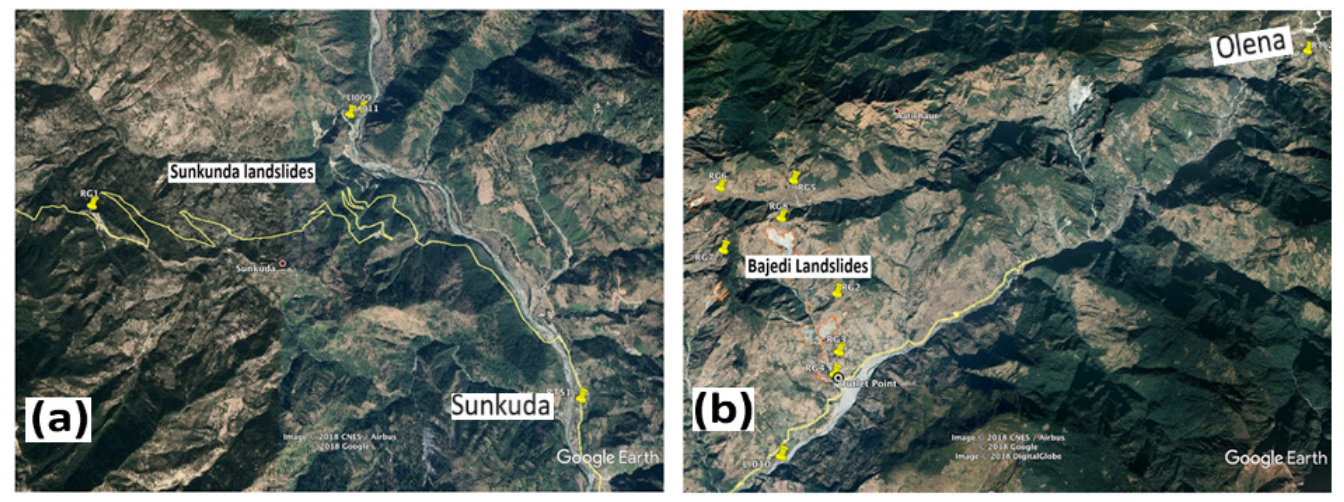

Figure 3: Location of landslides and meteorological networks (a) Sukunda landslide, Bajhang; (b) Bajedi landslide, Bajura .

\section{Data availability}

There are about 43 precipitation stations, which have been recording 24-hourly precipitation in the study area. All are manual rain gauges. Long-term data for the same period for all those stations are not available. In this study, 17 stations were selected. The long-term history of those 17 selected stations is personally known and verified; the time period of 1977-2017 has been considered based on these data. Mean monthly, seasonal and annual rainfall for all 17 stations for 1977-2017 were prepared and carefully evaluated. These data were extracted from the Government of Nepal (GoN), Department of Hydrology and Meteorology (DHM)'s internal databases. Among 43 rainfall stations, one station in Bajhang is close to the Sunkunda landslide, while another station in Bajura is within $1 \mathrm{~km}$ of the Bajedi landslide.

The hourly rainfall data was virtually not available in the study area; therefore, altogether, we installed another 13 automatic rain gauges at various locations (Figure 2b) in the landslide pilot area. Among these rain gauges, 12 are Davis $0.2 \mathrm{~mm}$ tipping bucket type (Davis Instruments Corp, 2017) fitted with a HOBO data logger. The remaining one is a Campbell Scientific $0.2 \mathrm{~mm}$ tipping bucket type, and is now operated by DHM. Ten of the gauges in the Bajedi area were installed on the associated landslide within a total area of $12 \mathrm{~km}^{2}$. All 13 stations are considered for hourly data analysis. Current data availability is for a very short time frame i.e. from May to November 2019; only two stations contain the full 2019 rainfall time series. 


\section{Data analysis}

Daily precipitation records of all stations were manually checked, compared with surrounding nearby stations, and outliers were screened. The mean, standard deviation and coefficient of variation of monthly and annual rainfall were calculated to check the rainfall variability. At the same time, mean monthly, seasonal and annual means of rainfall were also calculated. Simple linear regression (LOESS) was used to determine mean rainfall trends and coefficients of determination $\left(\mathrm{R}^{2}\right)$ for the significance of the trends. At the same time, statistical tools were used to check the rainfall variability of monthly and daily data (Arvind et al., 2017). Afterward, isohyets of average rainfall were generated for both long-term (1977-2007) and short-term (2007-2017) periods.

\section{Rain gauges and seasonal rainfall}

The seasonal rainfall at the two stations (Olena and Sunkuda) closest to the landslides in Bajedi of Bajura district is presented in Table 2. To visualise the patterns of rainfall in the study area, long-term data were tabulated and analysed along with four seasonal pattern of Nepal (Nayava, 1980): Winter (November-February), Pre-Monsoon (MarchMay), Monsoon (June-September), and Post-Monsoon (October).

Table 2: Seasonal rainfall at Olena and Sunkuda (2000-2017)

\begin{tabular}{|c|c|c|c|c|c|c|c|c|c|c|}
\hline \multirow{3}{*}{$\begin{array}{l}\text { Station } \\
\text { ID }\end{array}$} & \multirow{3}{*}{$\begin{array}{c}\text { Elevation } \\
\text { (m) }\end{array}$} & \multirow{2}{*}{\multicolumn{2}{|c|}{$\begin{array}{c}\text { Winter } \\
\text { (Dec-Feb) }\end{array}$}} & \multirow{2}{*}{\multicolumn{2}{|c|}{$\begin{array}{c}\begin{array}{c}\text { Pre- } \\
\text { Monsoon }\end{array} \\
\text { (Mar-May) }\end{array}$}} & \multirow{2}{*}{\multicolumn{2}{|c|}{$\begin{array}{l}\text { Monsoon } \\
\text { (Jun-Sep) }\end{array}$}} & \multirow{2}{*}{\multicolumn{2}{|c|}{$\begin{array}{c}\text { Post- } \\
\text { Monsoon } \\
\text { (Oct-Nov) } \\
\end{array}$}} & \multirow{3}{*}{$\begin{array}{c}\text { Annual } \\
\mathbf{m m}\end{array}$} \\
\hline & & & & & & & & & & \\
\hline & & Mm & $\%$ & $\mathbf{m m}$ & $\%$ & $\mathbf{m m}$ & $\%$ & $\mathbf{m m}$ & $\%$ & \\
\hline Olena & 1116 & 106 & 9 & 197 & 16 & 878 & 72 & 36 & 3 & 1217 \\
\hline Sunkuda & 894 & 67 & 6 & 166 & 14 & 939 & 76 & 57 & 5 & 1229 \\
\hline
\end{tabular}

The Kolagaun station, representative of the region's mean elevation and slope aspects, was selected to elucidate the seasonal variation of rainfall from 1975-2017 (Figure 4). The long-term annual average rainfall here is $1825 \mathrm{~mm}$; this station also represents well the extent of the landslides under consideration. 

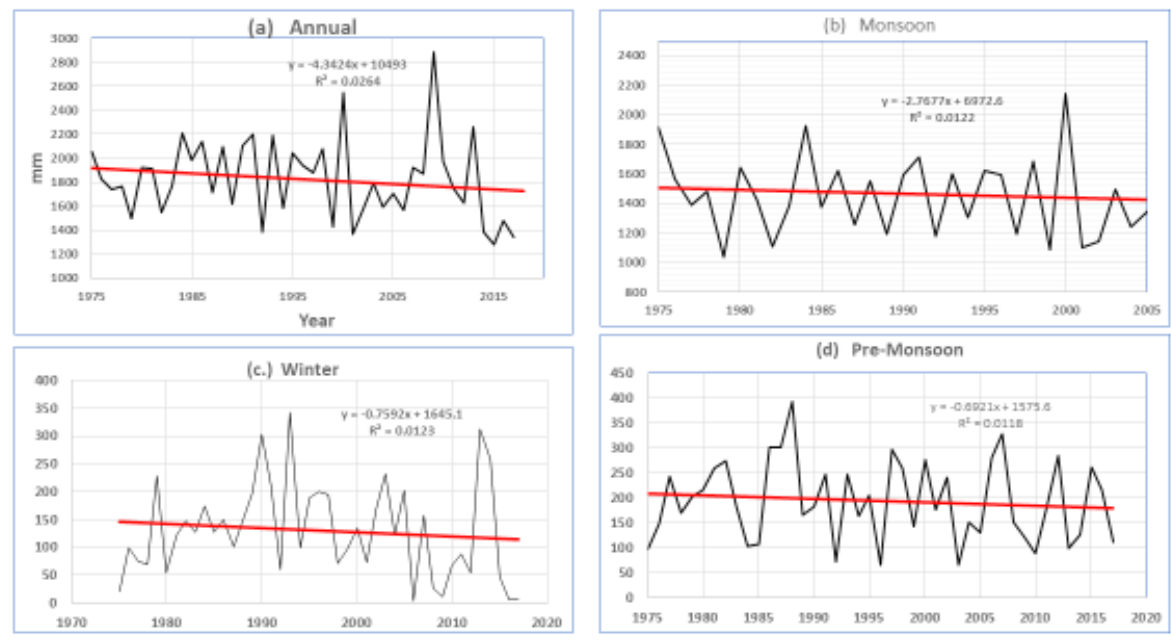

Figure 4: Trends of seasonal rainfall at Kolagaun, 1364 m elevation (a) pre-monsoon, (b) monsoon, (c) winter and (d) annual rainfall. Red line = trend line.

Figure 4 shows that rainfall decreases over all seasons. A post-monsoon panel is not represented, as it represents barely $1 \%$ of the total annual rainfall. These rainfall trends agree with those seen across the wider Hindukush Himalayas (Kieran et al., 2019). Moreover, they also agree with an observation of $\sim 70 \%$ of springs running dry over the past eight years across western Nepal (Adhikari et al., 2020). Far-western Nepal is the only region of the country where mean rainfall has decreased appreciably over the past $\sim 40$ years (Nayava, 2004).

\section{Characteristics of rainfall}

Table 3 shows that, in general, there are fewer rainy days at lower elevations across the region. Also, higher elevation stations might register strong orographic precipitation trends resulting from westerly disturbances. The distribution of recently-installed automatic tipping-bucket rain gauge stations according to altitude is shown in Table 4. 
Table 3: Rainy days (rainfall $>1 \mathrm{~mm}$ ) for the four different seasons of far-western Nepal

\begin{tabular}{|l|r|r|r|r|r|r|}
\hline \multirow{2}{*}{ Station } & Elevation, & \multicolumn{6}{|c|}{ Rainy days } \\
\cline { 3 - 7 } & $(\mathbf{m})$ & Winter & Pre-Monsoon & Monsoon & Post-Monsoon & Annual \\
\hline Jumla & 2384 & 14 & 26 & 72 & 1 & 113 \\
\hline Kolagaun & 1364 & 13 & 22 & 65 & 1 & 101 \\
\hline Dipayal & 563 & 16 & 16 & 54 & 0 & 86 \\
\hline Dhangadhi & 184 & 5 & 4 & 57 & 1 & 67 \\
\hline
\end{tabular}

Table 4: Coordinates of 13 automatic tipping-bucket rain gauges installed in 2018-2019

\begin{tabular}{|c|c|c|c|}
\hline & Latitude & Longitude & Elevation \\
\hline Station ID & (DD) & (DD) & (m) \\
\hline RG14 & 29.38 & 81.37 & 1020 \\
\hline RG4 & 29.37 & 81.35 & 1100 \\
\hline RG3 & 29.38 & 81.35 & 1162 \\
\hline RG17 & 29.50 & 80.87 & 1274 \\
\hline RG19 & 29.23 & 81.19 & 1400 \\
\hline RG11 & 29.38 & 81.33 & 1447 \\
\hline RG2 & 29.39 & 81.35 & 1524 \\
\hline RG1 & 29.50 & 80.85 & 1594 \\
\hline RG18 & 29.42 & 81.33 & 1860 \\
\hline RG12 & 29.42 & 81.33 & 1890 \\
\hline RG13 & 29.40 & 81.32 & 2030 \\
\hline RG15 & 29.40 & 81.32 & 2030 \\
\hline RG16 & 29.42 & 81.31 & 2042 \\
\hline
\end{tabular}

\section{Rainfall intensity}

One of the most important aspects of analyzing rainfall in relation to landslide occurrence is rainfall intensity. We therefore selected the Kolagaun station, where intensity has demonstrated important variations over the past $\sim 40$ years, to analyze hourly rainfall patterns. Figure 5 shows that the intensity of rainfall is increasing, with a particular spike in 2009 (465.4 mm). In recent years, extreme events have been ascribed to the effects of climate change and a 50-year rainfall cycle; a peak in rainfall intensity was noted (Figure 5). Many places in that area have registered similar high intensities of rainfall with associated anecdotal evidence of high-magnitude pluvial flood events. 


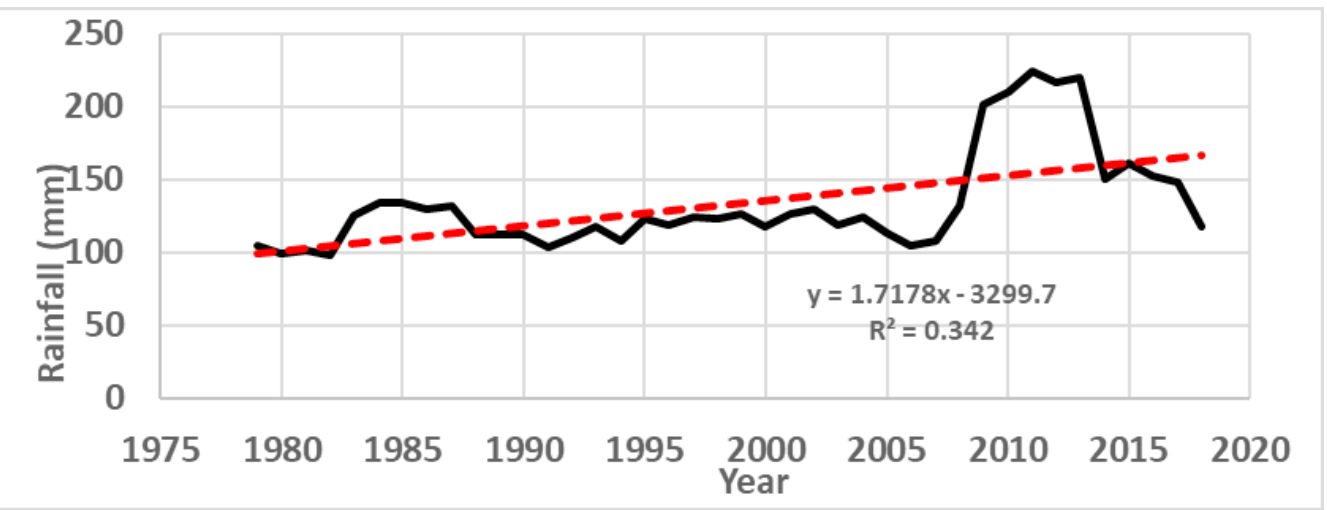

Figure 5: Five-year moving average (black line) of intensity of hourly rainfall (mm) at Kolagaun (1364 m elevation). Red line $=40$-year trend.

\section{Changing rainfall patterns in far-western Nepal}

Long-term rainfall data from 1977-2017 and short term data from 2007-2017 for 17 stations of Western Nepal were considered. These data were also collected and analysed to visualise general patterns of rainfall at a broader scale. Figure 6 demonstrate the decreasing magnitude of rainfall across far-western Nepal.

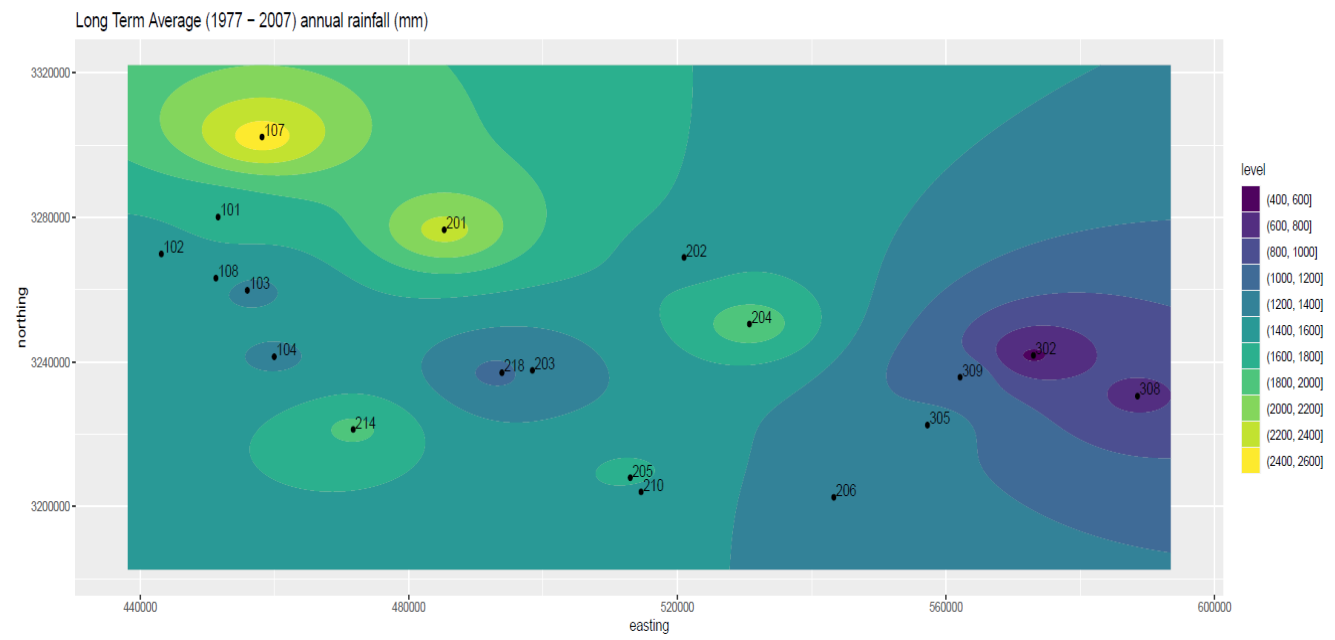




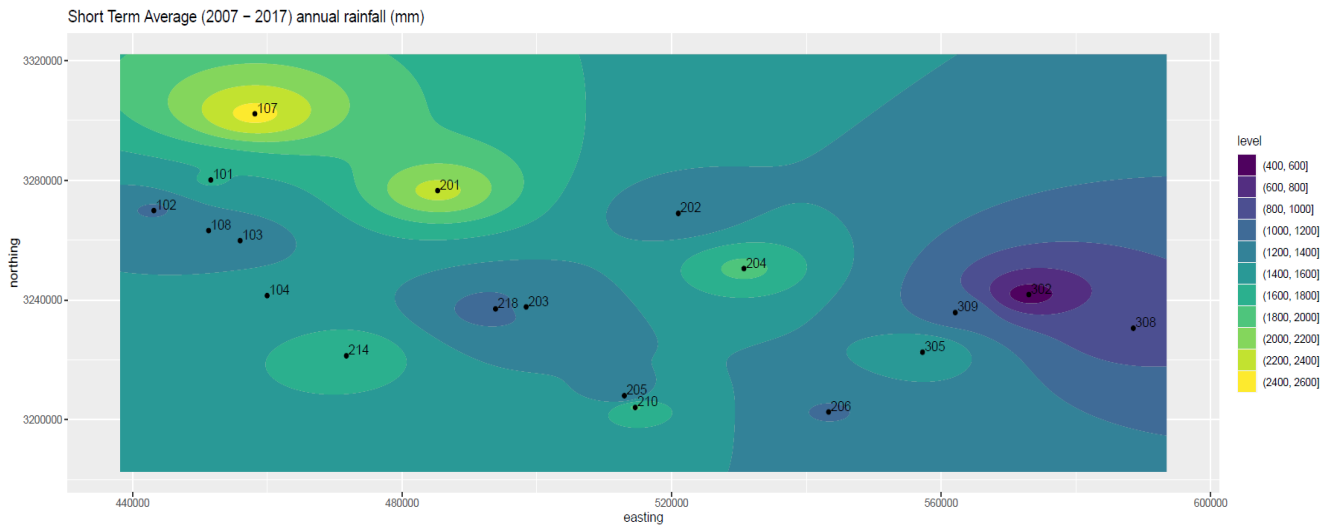

Figure 6: Long- (top) and short-term (bottom) mean rainfall for study area, far-western Nepal

\section{Results and discussion}

As already mentioned, data were not available virtually in the study area; therefore, we installed 13 automatic tipping bucket rainfall stations over a very small area $(\sim 42$ $\mathrm{km}^{2}$ ) with respect to slope, aspect and elevation (Table 4). To interrogate spatial rainfall patterns across the study area in greater detail, these more recent rainfall data were also retrieved, processed, and analysed. There are four categories of these new stations. There are only two stations in the Sunkuda landslide, both of which face northward (RG17 and RG1). Since we have only one season of rainfall at RG1, the rainfall distribution seems to agree with official DHM records; the total rainfall of the summer 2019 monsoon was $806.8 \mathrm{~mm}$. Over that period, the rainfall intensity over any 24 hours was generally less than $40.0 \mathrm{~mm}$ (Figure 7a). Similarly, total rainfall registered by RG17 was similar, while daily rainfall intensity was less than $\sim 50 \mathrm{~mm}$ throughout the 2019 monsoon.
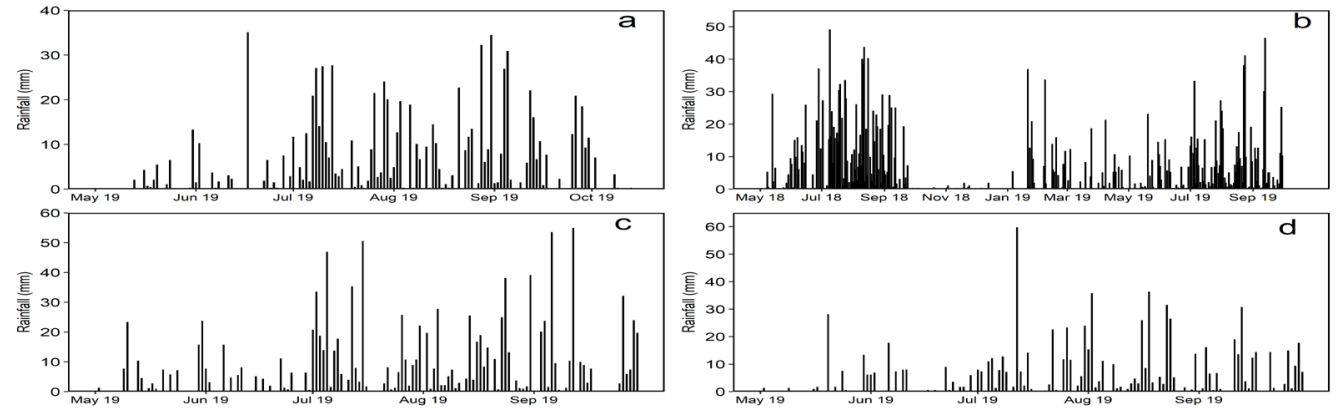

Figure 7: Daily rainfall totals at a) RG1, b) RG2, c) RG15 and d) RG14 
The three valley-bottom stations are RG4, RG14 and RG19. For two days in July and September 2019, daily rainfall intensity exceeded $50 \mathrm{~mm}$ for RG14 and RG11. Meanwhile, five other stations are located directly on the Bajedi landslide, facing south: RG2, RG3, RG11, RG13 and RG15. The final three stations are situated in an elevated valley $3 \mathrm{~km}$ northwest of the Bajedi landslide: RG12 (1890 m elevation), RG18 (1860 $\mathrm{m})$, and RG16 (2040 m). Table 5 summarises mean monthly rainfall totals for our newly installed automatic tipping-bucket rain gauges. In 2019, monsoon seasonal rainfall in far-western Nepal was slightly below normal levels (DHM, 2019).

Table 5: Monthly rainfall data from Davis rain gauges $(\mathrm{mm})$

\begin{tabular}{lrrrrrrrr}
\hline & \multirow{2}{*}{\begin{tabular}{c} 
Elevation \\
\cline { 3 - 8 } Station
\end{tabular}} & \multicolumn{1}{c}{ May } & \multicolumn{1}{c}{ June } & \multicolumn{1}{c}{ July } & \multicolumn{1}{c}{ Aug } & \multicolumn{1}{c}{ Sep } & \multicolumn{1}{l}{ Oct } & \multicolumn{1}{c}{ Nov } \\
\hline RG14 & 1020 & 60.4 & 75.8 & 343.8 & 250.4 & 192.6 & 0.8 & 0.2 \\
RG11 & 1116 & 77.4 & 119.0 & 403.8 & 268.2 & 387.2 & 33.4 & 2.2 \\
RG17 & 1274 & - & 76.2 & 347.8 & 263.2 & 151.2 & - & 3.4 \\
RG11 & 1447 & 52.6 & 100.6 & 386.4 & 228.4 & 219.4 & 0.2 & 0.2 \\
RG2 & 1524 & 77.2 & 62.4 & 370.6 & 245.2 & 246.8 & 1.0 & 0.2 \\
RG1 & 1594 & - & 77.4 & 278.8 & 299.8 & 214.4 & 16.0 & 0.2 \\
RG18 & 1860 & - & 78.0 & 315.4 & - & - & - & - \\
RG15 & 2030 & - & 81.0 & 519.0 & 389.2 & 383.6 & 13.0 & 0.2 \\
RG 16 & 2040 & 62.6 & 97.6 & 416.6 & 301.6 & - & - & 19.4 \\
\hline
\end{tabular}

\section{Relationship between landslides and rainfall}

The number of days of rainfall in the immediate vicinity of the Bajedi landslide was 8-12 over the course of the 2019 summer monsoon. This figure rose to a peak of 2325 days in July, followed by 20-25 in August, and 18-20 in September. We found a direct positive correlation between elevation and number of days in which rainfall was observed (Figure 8 ). The number of continuously rain days is arguably the key metric determining landslide occurrence (Petley et al., 2007). 

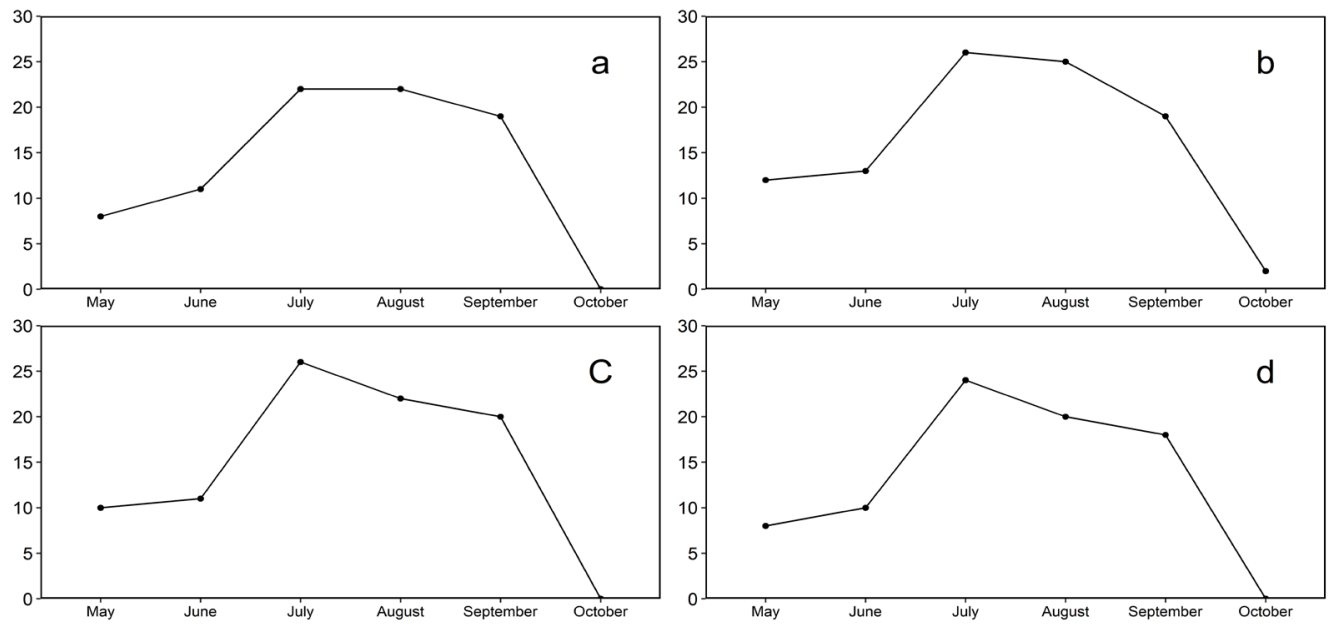

Figure 8: Number of rainy days during the 2019 monsoon registered by a) RG14, b) RG15, c) RG11, and d) RG2.

Similarly, the intensities of rainfall at the same stations over periods of 1, 2, 3, 6 and 12 hours are shown in Figure 9. The variation of intensities of rainfall over 1-12 hr was $18-76 \mathrm{~mm}$ at RG2 (1524 m). For a typical higher-elevation station, RG13, this range increased to $47-127 \mathrm{~mm}$. This strong variation across a single landslide validated our methodology of choosing multiple installation sites of increasing elevations up the landslide.
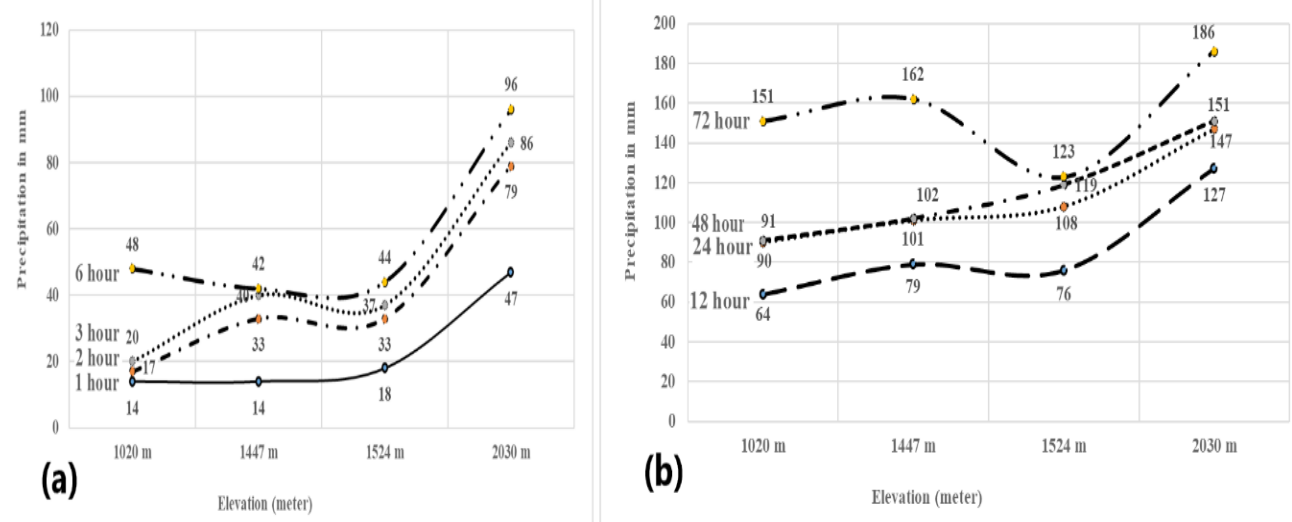

Figure 9: Rainfall intensities by elevation; (a) 1, 2, 3, 6 hours; (b) 12, 24, 48, 72 hours 


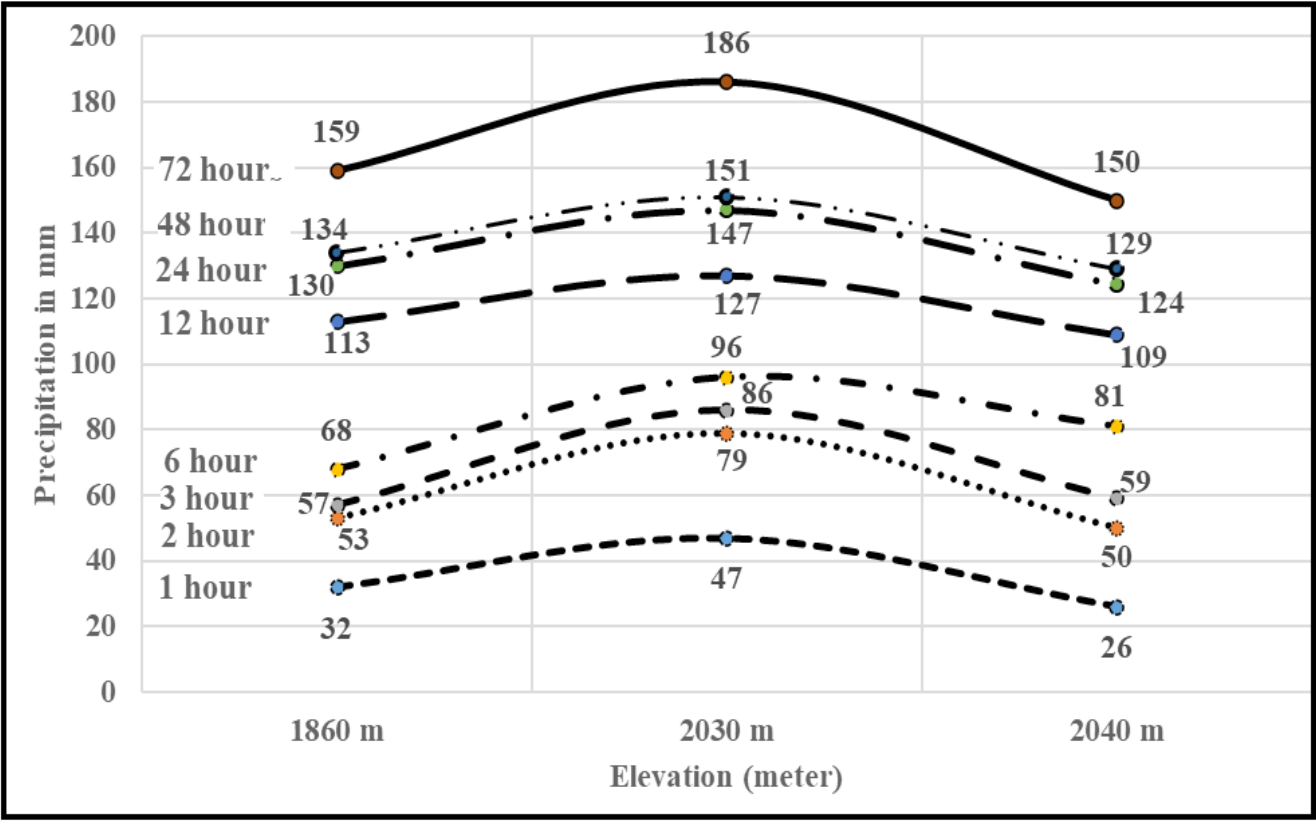

Figure 10: Rainfall intensities by elevation at 1,2,3,6, 12, 24, 48, and 72 hours - averaged in July 2019 (1860 m and $2040 \mathrm{~m}$ on leeward side, and $2030 \mathrm{~m}$ on windward side).

Figure 10 clearly indicates that rainfall intensities recorded on the leeward side of a hillslope are lower than the equivalent totals on the windward side. DHM derived that the threshold values for flood forecasting were $60,80,100$ and $120 \mathrm{~mm}$ of rainfall over 1, 2, 3, and 24 hours respectively (DHM, 2019). The rainfall intensities recorded by RG13 (Figure 9) generally exceed these threshold values. Elsewhere, rainfall intensity recorded by RG2 over 24-, 48-, and 72-hour periods was $60 \mathrm{~mm}, 91 \mathrm{~mm}$, and 145 $\mathrm{mm}$, respectively. For RG15 these values were $112 \mathrm{~mm}, 148 \mathrm{~mm}$, and $178 \mathrm{~mm}$ (Figure 9). Less rainfall was recorded on the leeward side of the hillslope (Figure 10). These values of rainfall intensity are "very high" in terms of mean monsoon rainfall across Nepal (DHM, 2019), suggesting a strong correlation with the high density of nearby landslides. The region's fragile and friable Miocene stratigraphy must be considered, along with over-zealous and unplanned road building, for development purposes. We discussed these factors with local community members at both study sites, explaining that the dominance of agricultural land correlates with greater-magnitude mudslides, which would have an important negative impact on local livelihoods and community cohesion. 
Cumulative rainfall variation over 1, 2, 3, 6, 12, 24, 48, and 72-hour periods across the study area (which changes in elevation from $1020 \mathrm{~m}$ to $2030 \mathrm{~m}$ ) was $14 \mathrm{~mm}, 47 \mathrm{~mm}, 48$ $\mathrm{mm}, 96 \mathrm{~mm}, 64 \mathrm{~mm}, 151 \mathrm{~mm}, 127 \mathrm{~mm}$, and $186 \mathrm{~mm}$, respectively. When one considers stations on leeside hillslopes only, the variation over 24,48 , and 72 -hour periods was $32 \mathrm{~mm}, 130 \mathrm{~mm}$, and $159 \mathrm{~mm}$, respectively. We speculate that the very active local monsoon season of 2020 could result from cleaner air arising from the Covid-19 pandemic (i.e. fewer flights and lower density of intensive transportation routes during national lockdown periods), a causal relationship that warrants further investigation. In far-western Nepal, the link to enhanced landslide activity was important, with a spike in fatalities and damage over 2019 and 2020 (Thapa, 2020). Landslide-damaged property losses were estimated at over US \$20 million, or double the total for 2018.

Understanding landslide risk necessitates an understanding of historical and current triggers, and the way in which their influence has waxed and waned over time. We also created an awareness of rainfall-induced landslides amongst the local communities, as well as their potential impacts on livelihoods, especially as several of the rain gauge stations were established within secondary school compounds (for additional security and maintenance purposes). This latter point allowed us to share our results with local educators and students and to introduce practical sessions using measuring cylinders to collect local household estimates of daily rainfall (Paul et al., 2020). This technique has been demonstrated to be very powerful in general awareness-raising of local landslide risk; the local community are better equipped to observe landslides themselves, and then to share inputs into local and regional disaster risk reduction (DRR) plans (Paul et al., 2018; Cieslik et al., 2019). Furthermore, we were also able to extend our rainfall sampling campaign and data analysis to collect data from 126 households in Bajura and 36 households in Bajhang, containing comprehensive information on demography, landslides and local resilience issues etc. This enabled us to link social/municipal data to rainfall metrics to produce a series of DRR recommendations for local municipal councils (Budhi Ganga, Chededaha, and Birthachaur rural municipalities). Subsequent discussions of general antecedents and triggers for local landslides, and their potential effects, enhanced local-level resilience and long-term capacity (especially allied to our work in local secondary schools).

\section{Conclusions}

Rainfall patterns in far-western Nepal exhibit important annual decreases over all seasons, especially winter rainfall, which is decreasing indeed across the entire Hindukush Region. Recent reports of springs drying up across western Nepal are also corroborated by the results of our study. In addition, we have demonstrated that rainfall intensity is increasing, which may lead to a greater range of hazards such as rapid flooding and more rapid and regular onset of landslides, especially in the local geologically fragile terrain (Miocene metaphyllites). We observed that rainfall 
intensities at lower elevations may not have reached assumed threshold values, but the highest-elevation station at $(2030 \mathrm{~m})$ registered significantly more rainfall than the associated threshold. If rainfall is uniformly continuous for 24-, 48-, and 72-hour periods, and the total cumulative rainfall exceeds $120 \mathrm{~mm}$, landslide events are likely to result, the effects of which being exacerbated by antecedent high soil saturations of that area, leading to massive mudslides. Therefore, when dealing with threshold values for flood forecasting or landslides, one should consider not only the rainfall registered by a single station, but also the probable rainfall over different elevations in the particular area, to give a more plausible and robust result. Otherwise, misleading early warnings may occur. We also suggest that engaging communities local to a particular landslide - for instance, by installing rain gauges in school compounds, or by conducting village discussion sessions - enhances local resilience and capacity against potentially lethal landslides and flood events.

\section{Acknowledgements}

We acknowledge funding from the UK Natural Environment Research Council (NERC) and Department for International Development (DFID) (contract NE/P000452/1) under the UK SHEAR (Science for Humanitarian Emergencies and Resilience) program (grant number NE/P000452/1). We also acknowledge the GoN Department of Hydrology and Meteorology (DHM) for their never-ending support in providing data.

\section{References}

Adhikari, S., Gurung, A., Chauhan, R., Rijal, D., Dongol, B. S., Aryal, D. and Talchabhadel, R. (2020). Status of springs in mountain watershed of western Nepal. Water Policy, 32, 1-20.

Arvind, G., Kumar, P. A., GirishKarthi, S. and Suribabu, C. R. (2017). Statistical analysis of 30 years rainfall data: A case study. Earth and Environmental Science 80012067.

Bappaditya, K., Nath, A., Saraswoti,S., Bandopadhyaya, K. and Roy, B. C. (2019). Assessment of rainfall thresholds for rain induced landslides activity in north Sikkim road corridors in Sikkim Himalaya, India. Journal of Geography, Environmental and Earth Science International, 19 (3), 1-14.

Cieslik, K., Shakya, P., Uprety, M., Dewulf, A., Russell, C., Clark, J., Dhital, M. R., Dhakal, A., (2019). Building resilience to chronic landslide hazard through citizen science. Frontiers in Earth Science, 7, 1-19.

Dahal, R. K. (2012). Rainfall-induced landslides in Nepal. International Journal of Erosion Control Engineering, 5(1), 1-8.

Desinventar: http/www.desinventar.net/desinventar/profile. Accessed on 18 November, 2020

DHM(2020). Climate reports 2020. Kathmandu: Department of Hydrology and Meteorology. 
DHM (2019). Monsoon monitoring 2019. Kathmandu: Department of Hydrology and Meteorology.

DHM (2017). Climatological and agrometeorological records of Nepal. Kathmandu: Department of Hydrology and Meteorology.

Dixit, A. (2003). Floods and vulnerability: Need to rethink flood management. In Natural Hazards, Journal of the International Society for the Prevention and Mitigation of Natural Hazards, Special Issue on Flood Problem and Management in South Asia, M.Q and Dixit, A, (eds.) 155-179. The Netherlands: Kluwer Academic Publisher.

Fischer, E. M. and Knutti, R. (2015). Anthropogenic contribution to global occurrence of heavy-precipitation and high-temperature extremes. Nature Climate Change, 5(6), 560-564.

Froude, M. J. and Petley, D. N. (2018). Global fatal landslide occurrence from 2004 to 2016. Natural Hazards and Earth System Sciences, 18(8), 2161-2181.

Gabet, E. J., Burbank, D. W., Putkonen, J. K., Pratt-sitaula, B. A. and Ojha, T. (2004). Rainfall thresholds for landslide in the Himalayas of Nepal. Geomorphology, 63(3-4), 131-143.

GoN (2019). Nepal Disaster Report 2019. Government of Nepal 1-54.

GoN (2009). Nepal Disaster Report 2009. Kathmandu: Ministry of Home Affairs, Government of Nepal, and Disaster Preparedness Network, Nepal with support from European Commission, United Nations Development and Oxfam, Nepal.

Ihaka, R. and Robert, G. R. (1996). A language for data analysis and graphics. Journal of Computational and Graphical Statistics, 5(3), 299-314.

Iverson, R. M. (2000). Landslide triggering by rain infiltration. Water Resources Research, 36(7), 1897-1910.

Kierran M. R. H., Andrew G. T. and Shaffrey, L. C. (2019) Falling trends of western disturbances in future climate simulations. Journal of Climate, American Meteorological Society, 5037-5051

Kirschbaum, D., Kapnick, S. B., Stanley, T. and Pascale, S. (2020). Changes in extreme precipitation and landslides over high mountain in Asia. Geophysical Research Letters, 47(4), 1-9.

Kumar, M. C., (2020). Loss of lives in the first 30 days of monsoon in the last 10 years. The Kathmandu Post, July 21, 2020

Nayava, J, L. (2017). Monsoonal rainfall and its impact on rice production in Nepal. Kathmandu: Rice Science and Technology, Crop Development Directorate and Agronomy Society of Nepal, Khumaltar, 497-506.

Nayava, J. L. (2004). The temporal variation of rainfall in Nepal since 1971 to 2000. Journal of Hydrology and Meteorology, 1, 24-33

Nayava, J. L. (1980). Rainfall in Nepal. The Himalayan Review, 12, 1-18. 
Nayava, J. L. (1974). Heavy monsoon rainfall in Nepal, Weather, 29, 443-450.

Parajuli, B. P., Khadka, P., Baskota, P., Shakya, P., Liu, W., Pudasaini, U., B.C., R., Paul, J. D., Buytaert, W., and Vij, S. (2020). An open data and citizen science approach to building resilience to natural hazards in a data-scarce remote mountainous part of Nepal. Sustainability, 12(22).

Paul, J. D., Cieslik, K., Sah, N., Shakya, P., Parajuli, B. P., Paudel, S., Dewulf, A., and Buytaert, W. (2020). Applying citizen science for sustainable development, rainfall monitoring in western Nepal. Frontiers in Water, 2, 1-12.

Paul J. D., Buytaert, W., Allen, S., Ballesteros-Canovas, J. A., Bhusal, J., Cieslik, K., Clark, J., Dugar, S., Hannah, D. M., Stoffel, M., Dewulf, A., Dhital, M. R., Liu, W., Nayaval, J. L., Neupane, B., Schiller, A., Smith, P. J. and Supper, R. (2018). Citizen science for hydrological risk reduction and resilience building. Wiley Interdisciplinary Reviews: Water, 5, e1262

Petley, D. N., Hearn, G. J., Hart, A., Rosser, N. J., Dunning, S. A., Oven, K., and Mitchell, Shrestha, P. M. (2020). Planned construction of rural roads and earthquake-hit geology blamed for the damages. The Kathmandu Post, August 4, 2020.

TCE (2002). Final report: Nepal irrigation sector project (Credit No. 3009, NEP). Kathmandu: Tahal Consulting Engineers Ltd. in association with GEOCE, ARMS, CEMAT.

Thapa, R.K. (2020). Losses of the life and property due to natural disaster during last five years. Naya Patrika-daily, July 19, 2020.

Trenberth, K. E. (2011). Changes in precipitation with climate change. Climate Research, 47(1-2), 123-138.

Upreti, B. N. (2001). Physiography and geology of the Nepal Himalayas and bearing on the landslides problem (special publication). Kathmandu: International Centre for Integrated Mountain Development, 31-49.

Upreti, B. N., Nakata, T., Kumahra, Y., Yagi. H., Okumura, K., Rockwell, T. K., Virdi, N. S. and Memoku, H. (2000). The latest active faulting in southeast Nepal. Proceedings of the Hokudan International Symposium and School in active faulting, 533-536.

Upreti, B. N. (1999) An overview of the stratigraphy and tectonics of the Nepal Himalayas. Journal of Asian Earth Science, 17, 741-753

UNDRR (2019). Disaster risk reduction in Nepal: Status report 2019. United Nations Office for Disaster Risk Reduction, 1-30.

Varnes, D. J. (1978). Slope movements, types and process of landslides, analysis and control. In Schuster R. L. and Krizek, R. J. (eds), Special Report No. 176, TRB. Washington D C: National Academy of Sciences.

W. A. (2007). Trends in landslide occurrence in Nepal. Natural Hazards, 43(1), 23-44. World Bank (2020). Global landslide hazard map. The World Bank. 